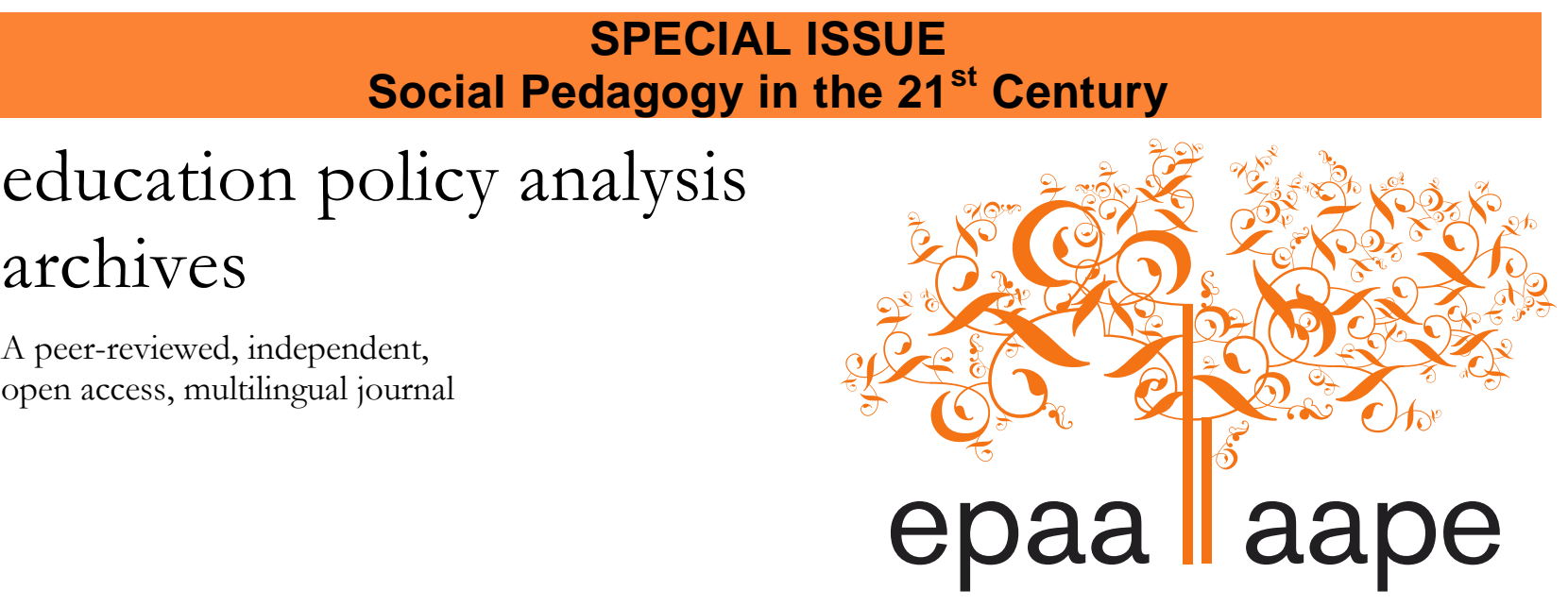

Arizona State University

\title{
Social Pedagogy and Liberal Egalitarian Compensatory Programs: The Case of Head Start
}

\author{
Shelly Lynn Counsell \\ University of Memphis
}

\author{
Robert M. Boody \\ University of Northern Iowa \\ United States of America
}

Citation: Counsell, S. L., \& Boody, R. M. (2013). Social Pedagogy and Liberal Egalitarian Compensatory Programs: The Case of Head Start. Education Policy Analysis Archives, 21 (39). Retrieved [date], from http://epaa.asu.edu/ojs/article/view/1299. This article is part of EPAA/AAPE's Special Issue on Social Pedagogy in the 21 ${ }^{\text {st }}$ Century, Guest Co-Edited by Dr. Daniel Schugurensky and Michael Silver.

Abstract: Using Head Start as an example of a compensatory social program based on a liberal egalitarian view of justice, this paper shows how all such programs are fundamentally flawed. In spite of any good intentions, by creating a discourse of deficiency and attempting amelioration through segregation this approach contains the seeds of its own failure. And, indeed, Head Start has floundered since its inception. That there is real need is clear; however, a new way forward is essential. We propose a model, based on social pedagogy, that takes seriously and respectfully the lifeworld of the children and families involved, and works cooperatively to find a way forward for everyone instead of imposing an externally-driven system response to an inadequately understood lifeworld. In addition, this reconceptualization must move beyond the exclusiveness of compensatory programs to inclusiveness of all children and families. This approach offers hope both for a more just social world in general based on deliberative justice as well as attaining goals of student achievement and development.

Journal website: http://epaa.asu.edu/ojs/

Facebook: /EPAAA

Twitter: @epaa_aape 
Keywords: compensatory programs; social pedagogy; Head Start.

\section{Pedagogía Social y programas compensatorios liberales igualitarios: el caso de Head Start}

Resumen: Usando Head Start como un ejemplo de un programa de compensación social basado en una visión de justicia liberal igualitaria, este trabajo muestra cómo todos estos programas son fundamentalmente erróneos. A pesar de las buenas intenciones, mediante la creación de un discurso de la deficiencia y tratar de mejorar a través de practicas de segregación este enfoque contiene las semillas de su propio fracaso. Y, de hecho, Head Start ha fracasado desde sus inicios. Es claro, que hay necesidad real, sin embargo, es preciso buscar un nuevo modelo. Se propone un modelo, basado en la pedagogía social, que tome en serio y con respeto la visión de mundo de los niños y las familias involucradas, y trabajar colaborativamente para encontrar un camino a seguir en lugar de imponer una respuesta desde un sistema externo que no comprende la visión de mundo de las familias involucradas. Además, esta re conceptualización debe ir más allá de la exclusividad de los programas compensatorios para la inclusión de todos los niños y las familias. Este enfoque ofrece esperanza, tanto para un mundo más justo, en general, basada en la justicia deliberativa, así como al objetivo de obtener logros educativos y de desarrollo.

Palabras clave: programas compensatorios; pedagogía social, Head Start.

Pedagogia Social e programas liberais igualitários compensatórios: o caso da Head Start Resumo: Usando o Head Start como um exemplo de um programa de compensação social com base em uma visão de justiça igualitária liberal, este artigo mostra como esses programas são fundamentalmente errados. Apesar das boas intenções, através da criação de um discurso da deficiência e tentar melhorar através de práticas de segregação esta abordagem contém as sementes de sua própria falha. E, de fato, o Head Start falhou desde o seu início. Claramente, há uma necessidade real, no entanto, deve-se encontrar um novo modelo. Propomos um modelo baseado na pedagogia social, que leva a sério respeitar a visão de mundo das crianças e das famílias envolvidas, e trabalhando em colaboração para encontrar um caminho em vez de impor uma resposta desde um sistema externo que não incluem a visão de mundo das famílias envolvidas. Além disso, esta reconceitualização deve ir além da exclusividade de programas compensatórios para a inclusão de todas as crianças e famílias. Esta abordagem oferece uma visão de esperança tanto para uma sociedade mais justa, em geral, baseada na justiça deliberativo, como os objetivos de obter conquistas educacionais de desenvolvimento.

Palavras-chave: programas compensatórios, treinamento puericultura, Head Start.

\section{Introduction}

Head Start was created to ameliorate pressing social needs by eradicating poverty through school readiness (for children representing the most severely economically disadvantaged). Programs and services were thus designed to enhance young economically disadvantaged children's cognitive, social, and emotional development (Head Start Act, 1965).

Throughout its history, Head Start's efficacy has been scrutinized, questioned, and ultimately challenged (e.g., Advisory Committee on Head Start Research and Evaluation, 1999; U.S.

Department of Health and Human Services, 2005; 2010; U.S. General Accounting Office, 1997; Westinghouse Learning Corporation, 1969). In spite of Head Start's struggles, an emerging body of evidence suggests that high quality early childhood programs can contribute to children's increased 
development, overall school readiness, and future success (Garces, Thomas, \& Currie, 2002; Gormley \& Gayer, 2005; Magnuson, Meyers, Ruhm, \& Waldfogel, 2004; National Institute of Child Health and Human Development [NICHD] Early Childcare Research Network, 2002; National Institute for Early Education Research [NIEER], 2009). As thirty-eight states now offer public preschool programs (NIEER, 2009), researchers and legislators increasingly wonder whether Head Start should continue as a national program or be devolved to the state-level (Besharov, 2009; Gormley, 2007; Henry, Gordon, \& Rickman, 2006; Nathan, 2007; Ripple, Gilliam, Chanana, \& Zigler, 1999; Vinovskis, 2008).

In this paper we argue that a more fundamental understanding of the rarely-challenged traditional notions about economic disadvantage, compensatory programs and practice needs to be addressed first (Besharov, Myers, \& Morrow, 2007; Henry et al., 2006; Ripple et al., 1999; Vinovskis, 1999). We offer Habermas' theory of communicative action as a useful conceptual framework to critique Head Start and find reasonable alternatives. From this vantage, we assert social pedagogical practices as proactive communicative action needed to move beyond distributive and egalitarian justice toward deliberative and empowered justice. In the rest of the paper we will discuss (a) Head Start's fundamental conceptual and historical orientation; (b) the limitations of its worldview and systemic response; (c) how Head Start could be re-conceptualized; and finally, (d) how to use social pedagogic communicative practices specifically to attain deliberative justice for all.

\section{The Foundations of Head Start}

Within the liberal-democratic tradition, Howe (1997) explained how equality of educational opportunity in public education is largely influenced by school purpose and the underlying assumptions about justice according to three predominant theories: libertarianism, utilitarianism, and liberal egalitarianism. Libertarianism strongly resists any involuntary form of distribution of social goods (like education, health services, and income). Utilitarianism rejects that stance, and actively (if not overtly) manipulates social arrangements to maximize benefits in ways that will best serve national economic productivity. The education report, $A$ Nation at Risk (National Commission on Excellence in Education, 1983), No Child Left Bebind (2001) legislation, and most recently, the Race to the Top competitive grants, were largely informed by a meritocratic utilitarian view of justice. The meritocratic utilitarian approach invariably forces the desire to equalize opportunity to compete with the overpowering goal to maximize productivity, which is presumed to be a function of finding the best people (thus meritocratic).

Liberal egalitarianism, as noted by Howe (1997), is best distinguished in terms of its conception of distributive justice. Liberal egalitarianism identifies individuals deemed as disadvantaged based on their limited access to, and possession of, essential goods and services needed to maximize life outcomes. In an attempt to remedy disadvantage and disparities, liberal egalitarians create educational opportunity, social programs, and economic incentives to help compensate individuals for their disadvantage resulting in a fair distribution of needed resources.

Clearly Head Start comes from an intellectual background of the liberal egalitarian approach to achieve distributive justice. Historical forces came together that produced a tide for it as well. The liberal egalitarian response to socio-economic disadvantage uncovered during the civil rights movements of the 1960s was the creation of compensatory programs intended for a wide assortment of marginalized groups who had previously been denied access (Berliner \& Biddle, 1995). The equity movement, guided by the liberal egalitarian worldview of disadvantage, became central to "the ferment for social justice that defined the political and cultural climate of that decade" (Bastian, Fruchter, Gittell, Greer, \& Haskins, 1993). 
At the same time, growing interest and enthusiasm toward early childhood education in the middle of the twentieth century was spurred on by changing views about children's intellectual development. Expert beliefs about children's intelligence prior to 1950 was that Intelligence Quotient (IQ) was fixed at birth and little could be done to alter it. Beliefs about intelligence in the1950s and 1960s began to change dramatically as experts argued that IQ was not exclusively determined by biology and the recognition that environment plays an important role (Bronfenbrenner, 1975; Bloom 1964; Hunt, 1961).

These two forces joined together in what many considered part of the Great Society's War on Poverty, Head Start. Social justice projects like Head Start were shaped by legal entitlements and social supports according to the historical and societal influences of that era. This program was intended to help young children overcome perceived deficiencies of their family and neighborhood (Zigler \& Anderson, 1979) and thus overcome poverty. President Lyndon Johnson, a former schoolteacher, was deeply committed in his faith and belief that education was the best means by which the government could eradicate poverty (Vinovskis, 1999).

\section{A Critique of Head Start}

Habermas' theory of communicative action can be a useful critical framework in better understanding policy and programs. Expanding on Mead's (1934) communication theory, Habermas (1987) envisioned communicative action as the "acts of reaching understanding" (p. 5) by social participants (communicative actors) to achieve cooperation and group consensus. Habermas utilized Durkheim's (1938) social theory to explain how social solidarity is reached cooperatively by virtue of individual efforts through the medium of language.

Habermas' theory of communicative action has been used as a critical framework in many areas. In the medical field, for example, Habermas' theory has been used constructively in the ongoing effort to reveal, understand, and improve upon doctor-patient communication in general practice (Barry, Stevenson, Britten, Barber, \& Bradley, 2001; Clark \& Mishler, 1992; Frank, 1995; Porter, 1998; Scambler, 1987). The strategic communicative action of technological medicine has been criticized for its systematic dominance in distorted communication patterns oriented to controlling patients (through technical rather than moral considerations) in order to achieve desired medical outcomes. Coyle (1999) interviewed patients and revealed that their medical treatment threatened their individual identity including perceptions of being dehumanized, objectified, stereotyped, disempowered, infantilized, and devalued. According to this study, women and individuals representing ethnic minority groups most often felt their intelligence had been undermined.

In response to rigid, largely repressive, distorted communicative action within social and medical fields across the Atlantic, radical social criticism in 1960s Germany challenged practices that pacified individuals within exploitive services. A limited, superficially detached external understanding of individuals is an insufficient view and interpretation according to the hermeneuticpragmatic pedagogical tradition. Accordingly, "individuals must be understood in terms of their own self-concept and the subjectivity of their own interpretative and habitual patterns" (Grunwald \& Thiersch, 2009, p. 135). Otherwise, the aspiration for success according to the systemic agenda (as often witnessed within the medical field) is ambivalent toward, and impedes the individual's own self-evidence, that in turn, lacks understanding of, or appreciation for the individual's everyday life. Understanding the everyday with a lifeworld orientation attempts to shift the focus from systemic control and domination toward understanding direct experiences, living contexts, life skills, and selfresponsibility. It is at the intersection of lifeworld experience of both communicative actors (service 
users and practitioners) in the everyday where conflicts between coercion and freedom and oppression and emancipation occur and may be continuously examined and addressed (Grunwald \& Thiersch, 2009).

\section{Head Start's liberal egalitarian lifeworld view of socio-Economic disadvantage}

Habermas (1987) conceptualized normative consensus of beliefs and values of any social group as the lifeworld, expressed and interpreted by social actors through communicative action forming the contextual horizon from which mutual understanding is achieved. Head Start's historical origin is the contextual horizon from which the "reservoir of taken-for-granteds" and "unshaken convictions" evolved, and then were translated through "collective processes of interpretation" (Habermas, 1987, p. 124) into the unchallenged lifeworld view of socio-economic disadvantage. Communicative action as envisioned by Habermas, are the "acts of reaching understanding" (p. 5) used to attain cooperation and group consensus among social participants. All societal enterprises like Head Start use communicative action (symbolically mediated interaction) primarily expressed through speech acts "in a cooperative process of interpretation" as communicative actors "relate simultaneously to something in objective, social, and subjective worlds" (p. 120). The lifeworld is conceptualized as the collective consciousness (i.e., values, attitudes, beliefs, assumptions, and convictions) used by communicative actors to make sense of their world.

The general lifeworld view of people living in poverty prior to 1950 in the United States was largely based on eugenics' beliefs about intelligence, talent, and heredity. This meritocratic utilitarian lifeworld view of ability and disadvantage presumed that individuals who occupied the lowest economic strata did so by virtue of their limited talents, skills, and abilities. At that time, the culture of poverty, as noted by Fischer (1985), was generally viewed as a "lower-class value system that denigrates hard work, discipline, and ambition and sacrifices future rewards for immediate gratification" (see Lewis, 1959). The outcome is "poverty resulting from slothfulness" (p, 247). Hence, the argument for compensatory programs originated with the argument that a culture (or subculture) of poverty diminishes or impedes life outcomes and opportunities for children in poverty.

Lifeworld views about people living in poverty were dramatically challenged after 1950 when experts questioned whether intelligence was actually fixed at birth and researched how the child's environment plays an important role in intellectual development. An increased focus on the role of environment led to the notion of cultural deprivation that first emerged during the 1960s and 1970s from social science and lay theories about social class differences in student achievement. Although the notion of cultural deprivation has long been refuted (Keddie, 1973), children's low academic performance from low-income groups, as noted by Brantlinger (2003), is largely attributed to insufficient intellectual stimulation in the home environment and parents' presumed lack of vested time and interest in their children's education; attitudes and beliefs that mirror Eugenics' assumptions about the poor.

The Great Society's liberal egalitarian worldview of economic disadvantage believed that helping children to overcome their social, cultural, and environmental deficiencies through compensatory programs that specifically targeted their deficiencies could improve and enhance children's intellectual development. Liberal egalitarians like the Johnson Administration wanted to eradicate poverty. Hence, Head Start was created with a two-part mission to: (a) help socioeconomically disadvantaged children overcome their perceived deficiencies of their family and neighborhood (Zigler \& Anderson, 1979) by increasing low-income children's IQ (that would likewise transfer to improved school readiness, a long-term goal that was not explicated by Congress 
until 1998), and (b) eradicate domestic poverty (by improving children's eventual competitiveness in the labor market).

From a social pedagogical view with a lifeworld orientation, Head Start's social efforts to eradicate poverty subsequently caught communicative actors (practitioners) in a conflict between respecting children and families' existing everyday structures and the system rationale to destroy the deficient everyday in order to strive toward a successful everyday (the system's rationale to improve school readiness and later economic prosperity needed to eradicate poverty). Without social pedagogical practices, it is easy for the system to suffocate and alienate communicative actors' lifeworld experiences (colonization) according to the system rationale rather than use the lifeworld orientation to better recognize, understand, and address communicative actors' issues, crises, and experiences. Not until the everyday lifeworld is accepted and understood by everyone will participating actors (namely practitioners and families) increase self-awareness and self-action as they co-construct meanings as fellow travelers through a shared journey of growth and empowerment (Smith, 2012). "The idea of education in community, through community, and for community" according to Hämäläinen (2012), "became an early conceptual determinant and methodological principle of social pedagogy" (p. 8). Empowering communicative actors as self-acting, social agents for change can directly influence and improve life conditions individually and collectively in ways that are most meaningful and purposeful to community members.

Head Start represented an early political and legislative victory for liberal egalitarians led by the Johnson Administration. However, this did not necessitate that all liberal egalitarians shared identical lifeworld views and beliefs about children who were economically disadvantaged (including the everyday lifeworld views and beliefs of families living in poverty) and what this meant for the program focus and anticipated outcomes. As a former schoolteacher, President Johnson believed deeply that education could help the disadvantaged (Vinovskis, 1999). According to Vinovskis, Johnson had "boundless faith in the efficacy of education in eradicating poverty was widely shared by many Washington policy makers" (p. 189).

The liberal egalitarian compensatory approach to distributing opportunity was also driven by meritocratic utilitarian mechanisms of cost-effectiveness and increased national productivity. In 1964, Edward Zigler was enlisted by the Johnson Administration as a panel expert to develop a program to help low-income children, and in 1965 he served on the National Planning and Steering Committee of Project Head Start. Four decades later, Zigler admitted Head Start's ambiguous mission and subsequent goals (system rationale) was detrimental to its early work. Unlike President Johnson and other liberal egalitarian policy makers, Zigler insisted,

Nobody on the committee thought that by working with 4-year-olds we were going to end poverty in America. The goal was simply to help kids avoid poverty later in their own lives by making them more ready for school, but we didn't state that in our planning document. (Perkins-Gough, 2007, p. 9)

While Liberal Egalitarian communicative actors like the Johnson Administration readily embraced Head Start as a much-needed compensatory program for socio-economically disadvantaged youth, other communicative actors (including libertarian and utilitarian policy makers) and the general public were less convinced. In an effort to help market Head Start to its skeptics, many liberal egalitarians (including the Johnson Administration) overemphasized (if not, exaggerated) the widely held hope (or promise) that Head Start would dramatically improve children's IQ and thus, eradicate poverty in the U.S. (Vinovskis, 1995). According to Zigler, policy makers (the liberal egalitarians) assumed that by improving school performance, children's IQs would likewise increase. From Zigler's perspective, this claim was a misguided misconception that 
has been very harmful to Head Start's long-term mission and overall success with continued consequences even today (Perkins-Gough, 2007).

\section{Head Start-A utilitarian system response to the lifeworld view of disadvantage}

The onset of emerging economies during the Industrial Revolution created the need for systems with steering capacities that could regulate and manage the new economies (Habermas, 1987). Systems are organized, highly rationalized social mechanisms and structural responses to accepted lifeworld agendas and priorities. Systems like Head Start are highly rationalized social organizations comprised of management designs and protocols, strategic and tactical actions, and policies and procedures, as well as efficiency and accountability assurances designed to achieve specific goals and outcomes (Sergiovanni, 2000). Given certain lifeworld views held by communicative actors, Habermas explains, decision makers respond by creating systems to carry out the goals implicit in the lifeworld beliefs.

Based on lifeworld beliefs about the poor prior to the 1950s as described abovemeritocratic utilitarian lifeworld view about learners and assumptions concerning their innate ability (merit) that largely reflected social class status - the system response was creating public schools with tiered curricula programs. Schools used differentiated curricula and sorted students according to academic or vocational tracks (steering mechanisms) in order to achieve the meritocratic system rationale of social efficiency (i.e., providing the greatest opportunity to the most capable learners who will best support and advance national economic productivity for the betterment of society). Hence, the academic or vocational track provided the necessary curriculum deemed commensurate with the individual learner's perceived aptitude (merit).

As the lifeworld view changed in the 1960s, a new system rationale was created by policy makers. Head Start's primary mission (system rationale) was to eradicate poverty by better preparing children living in poverty for entrance into elementary schools (as explicitly stated by Congress in 1998), that in turn would increase children's IQ and subsequently lead to increased long-term academic success and enhanced competitiveness in the labor market. Head Start statutes and regulations have established several primary eligibility criteria; at least one must be met for enrollment. Primary criteria include the child's family income is below the federal poverty level; the child's family is eligible or, in the absence of child care, would potentially be eligible for, public assistance; the child is in foster care; or the child is homeless. Head Start programs may also fill up to 10 percent of their slots with children from families who do not meet any of the above criteria, but who would benefit from participation in the program. Unless a program applies for and receives a waiver, at least 10 percent of each program's slots must be filled with children with disabilities who are determined to be eligible for special education and related services or early intervention services.

Unlike the new Title I program that was also established to help socio-economically disadvantaged children, Head Start was not an exclusively educational program nor housed in the Department of Education. As explained by Sissel (2000), Head Start was envisioned as a "'comprehensive social service provider' and outside the purview of traditional contexts of 'schools"' (p. 7). Today, Head Start is expected to additionally provide an array of health, nutrition, social, and psychological services. These services include family support, health screenings, and dental care. The Head Start program is overseen by the Department of Health and Human Services' (HHS) Administration for Children and Families and administered by the Office of Head Start (OHS). As one of the largest federal early childhood programs, it provides grants to local organizations (grantees) to operate Head Start programs.

Over the years there have been changes in Head Start. A companion program, titled Early Head Start, began in 1994 to provide services to pregnant women and children (birth to three years). 
Head Start operates both full- and part-day programs; the majority of Head Start programs operate during the school year. The Migrant and Seasonal Head Start program is designed to meet the specific needs of migrant and seasonal farm worker families.

The 1998 reauthorization added a new accountability and efficiency steering mechanism, the federal initiative, Good Start, Grow Smart. This initiative mandated that all 4-year-olds in Head Start programs must be assessed in areas based on 13 skills (Davis, 1998), coinciding with Congress' official declaration that Head Start's overarching goal was school readiness. These communicative actors (who have full access to legal and monetary steering mechanisms in the form of legislation and funding) arguably embrace and promote a meritocratic utilitarian orientation and lifeworld view of achievement and economic prosperity. Zigler complained that these politicians (utilitarians) were attempting to transform Head Start into a literacy-skills program (Perkins-Gough, 2007) heavily focused on cognitive development (much like the emphasis on IQ scores three decades earlier). These policy makers may argue for increased achievement for children in poverty (an Egalitarian pursuit). However, utilitarians can merit (justify) funding or no (unmerited) funding based on standardized test scores.

At the center of this debate, as suggested by Fischer (1985), are the principles of equal opportunity and the nature of egalitarian society (as influenced by Rawls's (1971) theory of justice) according to the liberal egalitarian worldview. These communicative actors emphasized the need for an egalitarian social order based on values of community and fraternity. The counter utilitarian worldview insists that the "good society emerges from the long-term social benefits of a meritocratic system based on the values of individual competition and native skill (generally measured as IQ)" ( $p$. 250). As Fischer concluded, communicative actors advocating for meritocratic (utilitarian) social order emphasized reading scores as the essential measurement of achievement (progress). In contrast, the communicative actors advancing the egalitarian cause believed that the achievement of the good society is determined by whether ideological principles of community and fraternity are attained. For Habermas, this kind of debate requires a "critique aimed at revealing both manifest and latent ideologies and domination in the exercise of social and political power" (as cited by Fischer, 1985, p. 250).

\section{Meritocratic utilitarian segregation based on income}

The 1960s liberal egalitarians believed that different kinds of disadvantage experienced by specific groups warranted specialized programs that would equalize educational results for those groups. This philosophical orientation was the basis for developing Head Start as a segregated program based on income. The liberal egalitarian's notion of equalization was a clear departure from the meritocratic utilitarian sorting that distributed opportunity according to presumed ability (or inability) that warranted the greatest educational and economic opportunity to individuals perceived as the most capable, skilled, or talented. In contrast, the creators of Head Start embraced the belief that IQ was not fixed and that early intervention in a specialized environment with enriched learning experiences would create a maximum learning opportunity for low-income children. Although Head Start was not envisioned as an academic track commensurate with ability, it was nonetheless meritocratic in the sense that it sorted children according to income from a deficit perspective, assuming that deficiencies of family and neighborhood warranted a separate (utilitarian) program designed to address specified needs.

Based on this liberal egalitarian system rationale, the system response developed a program limited to those with certain socio-economic characteristics. Liberal egalitarianism however, is not without its critics. Critical theorists like Bowles and Gintis $(1976,1989)$ have long criticized the liberal-democratic tradition as largely a product and reflection of a society dominated by economically powerful White males that ignores how class membership underpins privilege and 
power. In their seminal work, Schooling in Capitalist America (1976), Bowles and Gintis sought to demonstrate the failure of compensatory education programs' ability to achieve equal opportunity for all social actors within a capitalist social order. Based on the premise that the principle of equal opportunity functions to assert social control rather than actual social justice, Bowles and Gintis insist it is nothing more than a stabilizing force within capitalist societies.

Summarizing this critique, Howe (1997) concluded, "The liberal quest for equality is a sham because it serves merely to ensconce the status quo, rendering White males the standard of comparison and requiring disempowered groups to play by rules they had no part in formulating" (p. 31). As noted by Kantor and Lowe (1995), "no Black constituency demanded compensatory education during the Equity Movement; nor did any organized Black group participate in the formulation of federal legislation that endorsed compensatory practices" (p. 9). While Black leaders (e.g., W.E.B Dubois, Rev. Martin Luther King, Jr., and Malcom X) historically agreed on the need for increased educational opportunities, they unfortunately diverged and ultimately failed to reach consensus on which approach or strategy (steering media and mechanisms) could best achieve that aim (Berube, 1994).

At the end of this era of activism Bastian et al. (1993) noted that compensatory programs only achieved "a shift from exclusive meritocracy to inclusive meritocracy" (p. 76). That is, while compensatory programs like Head Start may have created new contexts or space for marginalized groups to participate, these programs succeeded only in creating new contexts based on merited need (inclusive meritocracy) using special activities deemed appropriate according to deficit/disadvantage assumptions. At the same time, these same marginalized groups continued to be excluded from other social (heterogeneous social networks), educational (inclusive early childhood programs), and economic opportunities (exclusive meritocracy) provided to other advantaged groups.

Segregated (utilitarian) programming (for any purpose) further perpetuates inequality by continuing to convince the same groups of learners (belonging to minorities, people with disabilities, and lower social classes) of their inferiority. Although the intent was to achieve social justice through more inclusive rather than exclusive practices, inclusive meritocracy was only conceded, while exclusive meritocracy persisted and, as a result, unequal (meritocratic) opportunities and utilitarian life outcomes have ultimately prevailed. Pressures to continue segregating children based on ability, language, or income (as in the case of Head Start) will not disappear anytime soon, and as suggested by Howe (1997), as long as access to increased opportunity is dependent upon measured achievement, the public education experience will continue to be largely mediocre, and consistently inadequate funding invariably forces compromises and difficult choices.

Furthermore, Boudon (1994) has suggested that egalitarian ideology was nothing more than a myth used to comfort middle class Americans while offering hope to the poor. As such, liberal egalitarian compensatory programs convince and reassure the general public that appropriate and adequate opportunities, experiences, and services are being rendered. Brantlinger (2003) likewise argued that compensatory programs and systems create professional jobs and roles, reassuring the middle-class of their own superiority while corporations prosper from the sale of remedies, and the poor continue to be blamed for the nation's economic struggles.

\section{Head Start's accountability and assurance steering mechanisms}

Within complex systems, steering media and mechanisms are used to sustain and maintain the systems' function and viability as essential to the lives of communicative actors (in this instance, children and families living in poverty). Powerful steering media like money, data, or political influence, can empower rationalized systems' ability to exercise direction and achieve ultimate control of lifeworlds (Gotz, 1997). The efficiency movement in education in the first half of the 
twentieth century ushered in the use of differentiated curriculum tracks and the subsequent need to create a scientifically based method for making objective placement decisions (Karier, 1986). The development of standardized IQ tests addressed the dual concern of humanity and efficiency by assigning different individuals to different instruction according to presumed abilities (meritocratic utilitarian selection).

With respect to Head Start, IQ test scores as a steering mechanism were not used for meritocratic ranking and sorting purposes since program placement was based on income, not IQ. Instead, IQ scores were used as an accountability steering mechanism to determine and document Head Start's efficacy. In 1969, Head Start suffered a serious setback when the Westinghouse Learning Corporation's evaluation of Head Start revealed that measured gains in children's IQ scores were small and faded quickly. Although the study praised some of the noncognitive benefits (such as social and emotional developmental gains), a political uproar ensued, with both proponent and opponent communicative actors engaged in a highly contested debate. The reputation of Head Start was severely weakened. The subsequent level of funding (an essential steering mechanism) for Head Start remained relatively stable throughout the 1970s and 1980s (in constant dollars) that largely meant sustainability but not growth (Vinovskis, 1993).

Perhaps the most devastating consequence of the Westinghouse study was President Richard Nixon's decision to postpone expanding a universal child care system; a meritocratic utilitarian decision. As head of the Office of Child Development, Edward Zigler devoted three years toward drafting a bill that would provide federal funding and set child care standards nationwide. While the bill passed both houses of Congress in 1971, President Nixon quietly vetoed the bill. Zigler refers to this bill's failure as "one of the most bitter defeats of my life" (Conniff, 2002).

Conflicting reports and evidence concerning Head Start's efficacy and impact continues to complicate Head Start's legacy. Evaluating Head Start's effectiveness in 1997 was a high priority by the U.S. General Accounting Office (GAO). After reviewing 600 articles and manuscripts, the GAO concluded, "The body of research is inadequate for use in drawing conclusions about the impact of the national program in any area in which the Head Start provides services such as school readiness or health-related services" (p. 2).

Two national randomized trials provided better information concerning the impacts of Early Head Start (Love et al., 2002) and the impacts of Head Start (Puma et al., 2005). Findings revealed Head Start produced positive effects for both groups, improving both social-emotional and cognitive development. Head Start's benefits for children and their parents were quite broad and included health and mental health, socialization, and cognition. However, the overall effects were quite modest. Effects on cognition and language were particularly small, with somewhat larger effects for narrow letter recognition skills that are easily taught. Head Start children's vocabulary scores were about a full deviation below the mean. An effect size of .10 was only a 10-20 percent reduction in that gap. Some higher quality state preschool education programs, as investigated by Barnett, Jung, and Frede (2007) were found to produce larger cognitive effects, including impacts on math. However, many state-funded preschool programs and curricula vary widely, performing no better than Head Start on average.

During the 1990s, both President George Bush and President Bill Clinton sought to expand Head Start funding that grew rapidly throughout that decade (Katz, 1996). Before the year 2000, more than $\$ 150$ billion had been spent on Title I and Head Start compensatory programs, yet the evidence continued to be mixed and unclear in substantiating which practices and programs effectively helped at-risk children (Vinovskis, 1999).

In fiscal year 2010, the Congress appropriated $\$ 7.2$ billion to serve approximately 900,000 children through approximately 1,600 Head Start grantees nationwide. The American Recovery and 
Reinvestment Act of 2009 (Recovery Act) provided an additional \$2.1 billion in funding for Head Start and Early Head Start. According to the Office of Head Start, the Recovery Act funds were designated for staff training, facility upgrades, and cost-of-living increases and were intended to allow certain programs to serve an additional 61,000 children and their families.

\section{Changing Diversity Lifeworld Beliefs and Systems through Social Pedagogy}

When systems fail to support and advance the lifeworld beliefs, values, or tradition of communicative actors, the lifeworld, according to Habermas, has been colonized by the system, overwhelming and subverting the lifeworld rationale with an opposing system rationale. Head Start was a systemic compensatory response to the liberal egalitarian lifeworld view of socio-economic disadvantage, the role that environment plays in learning and development, and their desire to subsequently eradicate poverty using distributive justice mechanisms.

In 1965, Head Start was a system response clearly tied to the policy maker's lifeworld view of poverty. We might ask, however, if this is still the case? In this discussion it is important to be clear as to which communicative actors we listen to and choose to follow.

Early childhood has long held the view that young children learn best by actively engaging with people and their surroundings (DeVries \& Zan, 1994). Piaget (1932/1965; 1948/1973) emphasized the child's social life as a necessary context for the development of intelligence, morality, and personality, and believed that intellectual, social moral, and affective developments are indissociable. Research studies increasingly reveal the complexity of how genes and environment interact to influence traits and characteristics. Research in probabilistic epigenesis suggest whether specific traits, characteristics, or behaviors will likely emerge over the course of development depends on the activation of the child's existing genetic potential by certain conditions (life experiences) in the environment (Gottlieb, 1997; 2003). Hence, every individual has many more potential developmental pathways than are ever realized. It is the child's environment that controls which parts of the child's genome are activated. Any significant change in the child's environment will significantly enhance or impede which genes will be expressed.

Modern developmental research further suggests increased cognitive competencies among young children (Gelman \& Brenneman, 2004; Newcombe, 2002). Ongoing modifications in neural structuring that take place as children grow and learn during the critical periods of development (prior to age 10) are likewise believed to begin to close around the fourth grade (Begley, 1996; Nash, 1997; Shore, 1997). Current brain research supports the urgent need to provide adequate and appropriate early learning and enrichment specifically and high quality early learning experiences in general. Failure to provide stimulating experiences places young children at greater risk for stunted or immature brain growth and development, particularly for children diagnosed with developmental disabilities or already considered at-risk for developmental delays.

Studies reveal that the quality of a child's home language environment at age 3 is a strong predictor of $10^{\text {th }}$ grade reading achievement. A child's vocabulary at age 4 is likewise predictive of grade 3 reading comprehension. Efforts to promote young children's language development must provide for high quality interactions between children in social learning contexts. Grouping children together with similar learning and developmental strengths and needs can potentially limit the level, quality, and range of educational opportunities and experiences within the learning environment.

Social pedagogy is a discipline with origins in $19^{\text {th }}$ Century Germany that is used broadly across Europe to underpin professional work with children and families (Smith, 2012). Social pedagogy varies widely across European countries and traditions, social theories, and systems of education and practice, but broadly speaking deals with the processes of human growth concerning 
socialization and strengthening the child's overall wellbeing that includes aspirations to prevent or alleviate social and developmental problems. Generally considered both a social science and profession, social pedagogy works with fundamental questions concerning societal order, human development, citizenship education, and social problems (Hämäläinen, 2012). While pedagogy generally refers to the nature of human growth and educational theory and practice, social pedagogy extends beyond child rearing and education to include community responsibility and provision (Petrie et al., 2006). The pedagogic approach applies a holistic view of the child (i.e., mind, body, feelings, sociability, and creativity) while pedagogues are actively engaged in everyday activities in a variety of program settings (social care, health, and education) used to promote children's overall development (Petrie, 2007).

Rosenthal and Jacobson's 1968 text, Pygmalion in the Classroom: Teacher Expectation and Pupils' Intellectual Development contributed a great deal to our understanding of the interrelationship between teachers' expectations and learners' self-fulfilling prophecies. In simple terms, the Pygmalion phenomena based on "the Oak School" experiment revealed that when teachers expect students to do well and show intellectual growth, students' growth reflects those expectations. When teachers do not have such expectations, performance and growth are not so encouraged and may in fact be discouraged. When students considered the most gifted are included in classroom instruction and learning, teachers' overall expectations for classroom learning and subsequent outcomes increase across all learners within diverse settings (Alderman, 2008).

Studies continue to reveal how teachers frequently equate high-income status with advanced achievement and high intelligence and low-income status with low skills and behavior problems (Brantlinger, 2003). Hence, many teachers (and parents) assume that students at low-income schools are less intelligent or at least less achievement oriented. When observing Head Start programs, Brantlinger was concerned about the lack of intellectual orientation that is typically found at private preschools. She concluded, "Program orientations and expectations for pupils surely figure into the differential readiness status of their respective pupils when they go on to kindergarten" (p. 84).

In an effort to move beyond personal and professional assumptions and experiences with different groups of people, social pedagogues are trained and educated in ways designed to be evermindful of how their underlying assumptions influence their practice as well as the extent to which their actions and reactions derive from personal and/or professional considerations as they work with individuals (Petrie, 2007). The importance of close personal and professional relationships between the social pedagogues and the children and families they work with cannot be denied or overstated. Social pedagogy conceptualized with Habermas' lifeworld orientation utilizes communicative action constructively within "interpersonal interaction characterized by focused, problem-solving actions, and by actions targeting the successful everyday, acting in proxy as appropriate" (Grunwald \& Thiersch, 2009, p. 140).

Many professionals in social and educational fields in the States now believe that maximizing learning and developmental outcomes for all learners depends on unrestricted access to people and activities across a variety of social settings (Brantlinger, 2003; Bogdan \& Taylor, 1994; Kliewer \& Biklen, 2007; Kluth, Straut, \& Biklen, 2003; Sailor, 2006; Storey, 1993; 2004; 2008). Increasing skill development across group participants creates a broader range of participation and performance, resulting in more varied learning opportunities for all participants than could otherwise be achieved in self-contained, homogeneous, segregated group arrangements or settings like Head Start. To limit or restrict access to a full range of experiences with diverse, socially integrated settings can limit both learning and life outcomes (Counsell, 2009). Diversity research suggests that if all other variables are the same, the learning and developmental outcomes achieved in segregated settings (like Head Start) would be exceeded if replicated in diverse early childhood settings. 
Thus, today, the liberal egalitarian lifeworld view of economic disadvantage that invariably led to a compensatory response to group differences within segregated (meritocratic utilitarian) settings is out of sync with current research. There is a growing sense in the broader society that liberal egalitarianism is not quite right, even if there is not yet a broad consensus on the next steps. Even Zigler, who played a key role in the creation of Head Start and has been a prominent defender, has questioned the practice of segregating children into specialized programs. As Zigler recently confessed,

I'm not sure that it's moral to segregate children along socioeconomic lines. I'm not sure it meets John Dewey's notion of educating children to live in a democracy. If you put kids from all social classes together, they get the benefits of learning about one another. And research now indicates that poor children's education accomplishments are greater when they are in classes with middle-class children than when they are in classes only with other poor children. (Perkins-Gough, 2007, p. 12)

Embracing rights perspectives is a central tenet in social pedagogy. Rather than prioritize concerns regarding risk and protection, social pedagogy requires a rebalance in current thinking to take greater account for individual rights, growth, and opportunity. An emphasis on individual rights and subsequent empowerment requires the abandonment of expert, supervisory, or counseling type relationships in favor of co-operative, co-constructors of meaning or fellow-travelers in journeys of lifelong growth and empowerment types. Equality and authenticity in relationships among communicative actors further serves to dissipate professional hierarchies through various joint activities.

Despite the fact that 38 states now provide integrative public preschool programs for the full range of learners, the fact that some communicative actors continue to insist upon the use of compensatory early intervention to improve life outcomes (regardless of the liberal egalitarian or meritocratic utilitarian argument) only confirms the ongoing colonization of the lifeworld view of economic disadvantage that results in segregated deficit tracking. For example, Besharov (2009) ponders whether Head Start is doing everything a program like it can do to compensate for family and community deficits. He argues that the research demonstrates that the "current" Head Start program as implemented (as a system), not the "idea" (lifeworld view) behind the program, is what has failed. Current research on early learning and development in light of Habermas' theoretical framework reveal that Head Start, as both a system and lifeworld view, is flawed both conceptually and in practice.

Mounting research suggests that all learners can benefit from diverse learning arrangements. However, this does necessitate that all parents are eager and willing to place their children in diverse settings. Kohn (1998) points out that, American schools are largely segregated and stratified by neighborhoods according to income. Even in schools that have diverse student populations, academic tracking based on merit segregates learners, with White students in honor classes and minorities largely occupying lower academic classes. Kohn questions whether inclusive education is possible in a largely exclusive (utilitarian) society. He charges it is the elitist parents driving a credentialing model of education intended to provide their children with advantage and privilege over less fortunate students. To confirm this belief, Kohn (1998) cites the confessed fatal assumption by one former superintendent, Mike McClaren in Oklahoma:

I thought if it was good for kids, everyone would embrace it, and I thought all adults wanted all kids to be successful. That's not true. The people who receive status from their kids' performing well in school didn't like that other kids' performance might be raised to the level of their own kids. (p. 570) 
Affluent parents of successful students are more likely to resist any kind of school reform if it would mean relinquishing advantage for their own children. As another educator in the same Oklahoma town concurred with the superintendent, "They are not concerned that all children learn; they are concerned that their children learn” (p. 570).

A key communicative action used in social pedagogy is the ongoing practice of reflection used by all participating actors-both practitioners and families-based in supportive relationships (Petrie, 2007). Through reflections, different groups of people (across regions, cultures, race, language, disability, and social class) with similar or competing concerns engage in active discussion to contemplate practice situations (like the context described above) and possible timing and contexts for both individual and collective action. Professional pedagogues continuously reflect on managing a balance between the personal and professional self, engaging in active listening while attending to children and families' rights. Communicative action is considered reflexive when it leads practitioners and families to affect and change each other in constructive, proactive ways. This is perhaps the most compelling practice used by social pedagogues to enact deliberative justice and empowerment for all communicative actors.

Critical analysis shows that more is at work when competing agendas emerge than simply research, evidence, and equity. For example, Besharov and Higney (2007) summarize politically opposing views, rhetoric, and competing agendas demonstrating the power and influence of steering media (money and politics) as follows.

Republicans... are reluctant to raise Head Start's problems for fear that Democrats and liberal advocates will paint them, yet again, as being against poor children. And Democrats are afraid that honesty about Head Start's weaknesses will sharpen the knives of conservative budget cutters. (p. 678)

Sissel (2000) provides a poignant example of the outward fear expressed by one Head Start advocate toward serious scrutiny of Head Start programs and outcomes that she encountered during a research presentation in 1994 on Head Start micropolitics. Sissel describes the interaction in the following words.

Angered about both the substance of my findings and the corresponding critique, a professor in the audience approached me after the presentation to insist that I not make this research public, for in his view to challenge the myth that local Head Start programs always functioned effectively on behalf of families and consistently dealt with parents in empowering and respectful ways would endanger the positive view that the public had of the program, and could potentially compromise the very program itself. (p. 10)

German sociologist and philosopher in the tradition of critical theory and pragmatism, Jürgen Habermas, is an internationally known proponent and champion of individual empowerment and deliberative justice. Acknowledging the critical role of individual agency, Habermas believes that "individuals are empowered when knowledge production and claims are legitimated through communicative action" (as cited in Counsell \& Agran, 2013). Deliberative justice emphasizes the "importance of debate among stakeholders to allow for an active interchange of ideas and values prior to decision making” (Morrow, 2011).

Mutual respect is a fundamental aspect essential to all meaningful relationships between communicative actors and is best achieved through reflective and reflexive activities within the everyday life. Strategically positioned communicative actors with the necessary cultural capital (political influence and money) need to engage in reflective and reflexive practices with both practitioners and families in order to reinvent Head Start in ways that will achieve empowerment and deliberative justice for everyone. Institutional resistance to change, long-term sustainability, and 
maintenance of program practices and structures can be attributed, at least in part, because they respond to influential agendas that serve to create and retain them (Bersoff, 1999; Schnog, 1997).

Based on more than 40 years of experience with Head Start, Zigler has realized that state legislatures are more likely to maintain funding for early childhood programs that represent and benefit the full range of legislators' constituencies. As communicative actors, poor parents lack the cultural capital that guarantees equal representation. Zigler provides a simple solution:

Poor people don't give money to congressional campaigns. They're not the voices we listen to closely. We listen to powerful, rich people...The only way you are going to have a preschool program that's safe from budget cuts and that gets funded for all the poor is by giving it to everybody. (Perkins-Gough, 2007, p. 12)

Social Pedagogy with a lifeworld orientation, as argued by Grunwald and Thiersch (2009), has the potential, if not a lifeworld vision, to create a social culture that more accurately reflects a just society. With an emphasis on "professional support, networked in a social environment with a lifeworld orientation," social pedagogues actively engage "civil self-help and self-advocacy, and appropriate social policy" needed to bring about "a successful everyday for people struggling with the strains and problems of their life situations" (p. 144).

\section{Repositioning Head Start for Deliberative Justice and Empowerment}

In summary, then, we can say that Head Start is a liberal egalitarian compensatory system response to economic disadvantage. It uses both meritocratic utilitarian sorting (and segregating) mechanisms based on income and meritocratic utilitarian assurances (based on IQs or test scores) to demonstrate cost-effectiveness and productivity. Liberal egalitarian communicative actors like the Johnson Administration and Congress reached consensus that the creation of new compensatory programs and services were needed to achieve social (distributive) justice for young children representing economically disadvantaged families (lifeworld view). Deficit hypotheses undergirded the beliefs and assumptions about underachieving students and remedies (like Head Start's compensatory interventions) designed to improve or eradicate their assumed inadequacies (Foucault, 1983; Reiter, 2000; Skrtic, 1991; Sleeter, 1996).

Decades later, the ambitious hopes that domestic poverty would be eradicated have not been realized. By all accounts, Head Start has largely failed to provide children who are severely economically disadvantaged with adequate intervention needed to "overcome their disadvantages, compete equally, and successfully with their middle-class counterparts" (Vinovskis, 1999, p. 199). The Head Start Impact Study (2010) reported that while children's participation in Head Start resulted in benefits in the cognitive, health, and parenting domains for three- and four-year-olds and in the social emotional domain for 3-year-olds only, these benefits largely fade by first grade.

Distributive justice is weighed according to the relative worth of the measured outcomes attributed to social policy (Morrow, 2011). Rather than continue to exhaust valuable resources futilely attempting to demonstrate program efficacy (based on distributive justice) over and over again, it would seem far more productive, as Besharov (2009) suggests, to abandon this folly in order to begin the "difficult and unglamorous work of systematic program improvement" (p. 199) or complete systemic reinvention using a deliberative justice process. Wagner and Kegan (2006) insist that attempts to reform systems typically result in only modest, incremental change. Only reinvention leads to adaptive change for individual communicative actors.

We propose starting the rethinking with the point that all liberal egalitarian compensatory programs, including Head Start, are fatally flawed from their inception. This fatal flaw lies at its core (lifeworld view) and is further translated into flawed practice (segregation). The intent was to help 
poor children by giving them what they lacked from their background (distributive justice). This whole concept begins from the assumption that it is their personal lacks that keep them poor rather than an economic system arrayed against them. And it assumes that targeting the needy is the best solution. Contemporary thinking suggests the opposite; student achievement and development as well as social (deliberative) justice is best achieved through individual empowerment and full participation as valued community members within integrated educational activities and settings. We suggest that any compensatory program, regardless of good intentions, is conceptually flawed in its distributive justice scheme, and will invariably fail or fall short of achieving the social goals set forth.

This is not to suggest that the broad goal of providing equitable access to education and other social goods is not an issue. It is. Across the nation, an academic achievement gap persists between social classes. Reardon (2011) reported that family income is more determinative of educational success than race. Low-income families are increasingly stretched for time and resources, impacting school readiness and overall academic performance as measured by test scores. In 2007, wealthy parents spent 9 times as much per child as low-income families. Sawhill (2006) further raised the concern that the U.S. educational system reinforces differences in students' family backgrounds.

\section{Achieving empowerment for all communicative actors}

While Head Start has historically struggled to maximize low-income children's learning and developmental outcomes, it has excelled, according to Zigler, in terms of its ability to provide comprehensive services related to health and nutrition for young children and families. It has also been suggested that Head Start has made significant contributions with respect to parent involvement, and in this aspect, has enhanced parental empowerment. Developed out of the Office of Economic Opportunity and directly linked to the Community Action Program, Head Start was conceptualized as an egalitarian program that would likewise pioneer parent involvement, empowering the poor through decision-making opportunities within the program, and increase economic independence through job placement at Head Start centers. However, even in this instance, community action was an ambiguous construct that the legislation failed to adequately define according to its "nature, extent, level, goals, consequences, or standards of participation" (Zarefsky, 1986, p. 45).

According to Gillette (1996), the War on Poverty achieved through community action meant that poor social actors' involvement was central and necessary to "energize impoverished neighborhoods needed to combat poverty" (p. xix). By documenting the oral histories of key communicative actors (policy makers, politicians, and bureaucrats), Gillette delineates the many conflicting worldviews of community action and whether there was consensus that the intended purpose was to increase empowerment and emancipation for the poor.

As illustrated by Adam Yarmolinsky, chief of staff for the War on Poverty Task Force, the notion of maximum feasible participation "meant that you involved poor people in the process, not that you put them in charge" (Gillette, 1996, p. 77). Kermit Gordon, former director of the Bureau of the Budget concurred with that sentiment, stating "I'm sure all of us at that time thought of community action as organized, controlled, and managed in a sense by elite groups-by the city government, by business groups, by churches, by labor unions, by nonprofit social organizations, welfare bodies, etc.” (p. 78).

Daniel Patrick Moynihan (1969) explained that Community Action Programs were intended to merely provide services to the poor rather than achieve any higher aspirations of empowerment. Community Action legislation, according to Moynihan was crafted in such a way as to "ensure that those persons excluded from the political process in the South and elsewhere would nonetheless participate in the benefits of the community action programs of the new legislation" (p. 87). Yet, 
other political and bureaucratic egalitarians like Frank Mankiewicz, director of the Peace Corps, dismissed Moynihan's charges. Mankiewicz insisted the designed mission of community action was to challenge power structures through collective action that included active input and participation of the poor (Gillette, 1996, p. 86). These kinds of contradictory and conflicting worldviews confused and undermined the egalitarian pursuit of equal opportunity that simultaneously opened the door to local power struggles (p. xvii).

In an in-depth comparative case study of two Head Start centers, Sissel's critical analysis illuminated the "micropolitics that exist within 'schools' when staff and parents are confronted with inadequate resources, contradictory ideologies, and unequal mechanisms of power, privilege, and control" (cited in Sissel, 2000, p. 9). Much like the criticism that technological medicine systematically distorts communication patterns to dominate and control patients in order to achieve desired medical outcomes, Sissel contended that the micropolitics at the local Head Start centers she observed help shape similar mechanisms of power and control through the allocation and distribution of resources, information, parent participation, and staff interactions with parents. In opposition to Head Start's professed promises of empowerment, Sissel's investigation revealed a "hidden curriculum of disempowerment" for the parents included in the study (pp. 11-12). In conclusion, Sissel challenged:

We must question how a program can work towards justice at any level when the system and those within it engage in and support action that are oppressive, and that further marginalize those that it is supposed to empower. (p. 281)

Equal opportunity is a central tenet and legitimating principle of liberalism. As pointed out by Fischer (1985), "educational institutions (designed for social mobility through the principle of merit) are the primary vehicles for the realization of equal opportunity" (p. 237). As Fischer suggested, to achieve long-term success it is imperative that compensatory programs like Head Start socialize children in poverty in ways that will adequately prepare them as future citizens. By doing so, the system can then avert from what Habermas (1971) refers to as a legitimation crisis. Is the social legitimacy of Head Start the outcome of true empowerment and emancipation or immersion and indoctrination of future generations? Assuring policy legitimacy for Habermas depends on the inclusion of both individual and collective lifeworlds in an ideal free speech situation. The more citizen input (communicative action) and deliberation is guaranteed, the greater the chance for creation of legitimate policy even if disagreement remains.

\section{Embracing a lifeworld view and system response to diversity for a diverse society}

If the lifeworld view embraces empowerment and social justice for low-income children, it is imperative to determine whether Head Start can be reinvented into, or repositioned as, a universal early childhood program that serves the full range of learners across all demographic groups. A national policy for universal preschool is needed to facilitate the development of an effective, comprehensive early education and care system. Zigler and Finn-Stevenson (2007) now promote a vision for early education and care system referred to as the School of the $21^{\text {st }}$ Century (21C). $21 \mathrm{C}$ is a comprehensive school-based program that includes universally accessible preschool education, child care, and other services from conception to age 12. Zigler and Finn-Stevenson recommend six guiding principles for $21 \mathrm{C}$ programs: (a) early childhood education and care must be prioritized nationally as an essential societal structure; (b) good quality care must be accessible to every child regardless of racial, ethnic, or socio-economic group; (c) child care practices must be based on a whole-child approach that attends to all developmental pathways (i.e., social, emotional, physical, language, and cognitive); (d) parents and care givers must work collaboratively to ensure developmental continuity; (e) recognition, support, and appropriate pay for child care providers 
(who are key to providing quality care); and (e) a national child care system must be flexible and adaptable, allowing for family dynamics while providing a range of choices for child care.

In light of accumulated research concerning the learning and developmental benefits of diverse educational settings, Head Start as a system must now be held accountable for its continued meritocratic utilitarian practice of segregating children according to income and the consequences of distributive justice for learning and instruction that result. Building on ideas such as those promoted by $21 \mathrm{C}$, a new system response could be developed that can meet the original high-level intention of Head Start to increase social equity for low-income children.

Communicative actors who practice social pedagogy must utilize a combination of intellectual, emotional and practical abilities and skills. Social pedagogy capitalizes on the close personal and professional relationships between professionals and the children and families they work with, negotiating the boundaries within everyday life. Everyday relevance places "lowthreshold and holistic social care in the service user's lifeworld" (Grunwald \& Thiersch, 2009). A holistic view of children during active engagement in everyday activities is used to promote children's overall development. Social pedagogy with a lifeworld orientation is used to understand and construct the life-space from which communicative actors learn to "interact, build relationships, and feel included" (Smith, 2012, p. 51). Reflective and reflexive practices promote mutual respect as communicative actors interact in ways that affect and change each other during meaningful everyday life activities and experiences. Without the fatal flaw of Liberal Egalitarian distributive justice at its heart, the adoption of a reinvented lifeworld view of diversity and economic disadvantage supported by social pedagogy and based on deliberative justice and empowerment that includes all voices might make actual progress for children and families across all socio-economic groups.

\section{References}

Advisory Committee on Head Start Research and Evaluation. (1999). Evaluating Head Start: A recommended framework for studying the impact of the Head Start Program. Washington, DC: U.S. Department of Health and Human Services.

Alderman, T. (2008). Meeting the needs of your most able pupils: Science. New York, NY: Routledge.

Barnett, W. S., Jung, K., \& Frede, E. (2007). Impacts of New Jersey's Abbott Preschool Program on children's language, literacy, and math skills. New Brunswick, NJ: National Institute of Early Education Research.

Barry, C. A., Stevenson, F. A., Britten, N., Barber, N., \& Bradley, C. P. (2001). Giving voice to the lifeworld. More humane, more effective medical care? A qualitative study of doctor-patient communication in general practice. Social Science and Medicine, 53, 487-505.

Bastian, A., Fruchter, N., Gittell, M., Greer, C., \& Haskins, K. (1993). Three myths of school performance. In H. S. Shapiro \& D. E. Purpel (Eds.), Critical social issues in American education: Toward the 21 ${ }^{\text {st }}$ century (pp. 67-84). White Plains, NY: Longman Publishing.

Begley, S. (1996, February 19). Your child's brain. Newsweek, 41-46.

Berliner, D. C., \& Biddle, B. J. (1995). The manufactured crisis: Myths, fraud, and the attack on America's public schools. White Plains, NY: Longman Publishing.

Bersoff, D. M. (1999). Explaining unethical behavior among people motivated to act prosocially. Journal of Moral Education, 28(4), 413-428.

Berube, M. R. (1994). American school equity: Progressive, equity, and excellence movements, 1883-1993. Wesport, CT: Praeger.

Besharov, D. J. (2009). Presidential address: From the Great Society to continuous improvement government: Shifting from "Does it work?" to "What would make it better?" Journal of 
Policy Analysis and Management, 28(2), 199-220.

Besharov, D. J., \& Higney, C. A. (2007). Point/Counter: Head Start: Mend it, Don't expand it (yet). Journal of Policy Analysis and Management, 26(3), 678-681.

Besharov, D. J., Myers, J. A., \& Morrow, J. S. (2007). Costs per child for early childhood education and care: Comparing Head Start, CCDF child care, and prekindergarten/preschool programs. College Park, MD: Welfare Reform Academy. Retrieved June from http://www.welfareacademy.org/pubs/childcare_edu/costperchild.pdf

Bloom, B. S. (1964). Stability and change in buman characteristics. New York: Wiley.

Bogdan, R., \& Taylor, S. J. (1994). The social meaning of mental retardation. New York, NY: Teachers College Press.

Boudon, R. (1994). The art of self-persuasion: The social explanation of false beliefs (M. Slater, Trans.). Cambridge, England: Polity Press.

Bowles, S., \& Gintis, H. (1976). Schooling in capitalistic America: Educational reform and the contradictions of economic life. New York, NY: Basic Books, Inc.

Bowles, S., \& Gintis, H. (1989). Can there be a liberal philosophy of education in a democratic society? In H. A. Giroux \& P. McLaren (Eds.), Critical pedagogy, the state, and cultural struggle (pp. 24-31). Albany, NY: State University of New York Press.

Brantlinger, E. (2003). Dividing classes: How the middle class negotiates and rationalizes school advantage. New York, NY: RoutledgeFalmer.

Bronfenbrenner, U. (1975). Is early intervention effective? In M. Guttentag \& E. L. Struening (Eds.), Handbook of Evaluation Research, Vol. 2 (519-603). Beverly Hills, CA: Sage.

Clark, J. A., \& Mishler, E. G. (1992). Attending to patients' stories: Reframing the clinical task. Sociology of Health and Illness, 14, 344-372.

Conniff, R. (2002, June). The progressive interview. The Progressive, 30-35.

Coyle, J. (1999). Communication between provider and patient: Values, biography, and empowerment in clinical practice. Aging and Society, 16, 747-774.

Counsell, S. (2009). Abandoning the least restrictive environment in favor of natural settings: The achievement of social justice for all-It's a right not a privilege! The Constructivist, 20(1), 1-30.

Counsell, S., \& Agran, M. (2013). Understanding the Special Olympics debate from lifeworld and system perspectives: Moving beyond the Liberal Egalitarian view toward empowered recreational living. Journal of Disability Policy Studies, 23(4), 245-256.

Davis, A. (1998). The limits of educational assessment. Oxford, England: Blackwell Publishers.

DeVries, R., \& Zan, B. (1994). Moral classrooms, moral children: Creating a constructivist atmosphere in early education. New York, NY: Teachers College Press.

Durkheim, E. (1938). The rules of sociological method. Chicago, IL: The University of Chicago Press.

Fischer, F. (1985). Critical evaluation of public policy: A methodological case study. In J. Forester (Ed.), Critical theory and public life (pp. 231-257). Cambridge, MA: MIT Press.

Foucault, M. (1983). The subject and power. In H. L. Dreyfus \& P. Rabinow (Eds.), Michel Foucault: Beyond structuralism and hermeneutics (pp. 208-226). Chicago, IL: University of Chicago Press.

Frank, A. (1995). The wounded storyteller. Body, illness and ethics. Chicago, IL: The University of Chicago Press.

Garces, E., Thomas, D., \& Currie, J. (2002). Longer-term effects of Head Start. The American Economic Review, 92(4), 999-1012.

Gelman, R., \& Brenneman, K. (2004). Science learning pathways for young children. Early Childhood Research Quarterly, 19(1), 150-158. 
Gillette, M. L. (1996). Launching the War on Poverty: An oral history. New York, NY: Twayne Publishers. Gormley, W. (2007). Early childhood care and education: Lessons and puzzles. Journal of Policy Analysis and Management, 26(3), 633-671.

Gormley, W., \& Gayer, T. (2005). Promoting school readiness in Oklahoma. Journal of Human Resources, 40, 533-558.

Gottlieb, G. (1997). Synthesizing nature-nurture: Prenatal roots of instinctive behavior. Mahwah, NJ: Erlbaum.

Gottlieb, G. (2003). On making behavioral genetics truly developmental. Human Development, 46, 337-355.

Gotz, N. (1997). Communication and instrumentalization. On a theory of sustainable development of collective identities (M. Dale, Trans.). Berlin, Germany: Humboldt University.

Grunwald, K., \& Thiersch, H. (2009). The concept of the 'lifeworld orientation' for social work and social care. Journal of Social Work Practice, 23(2), 131-146.

Habermas, J. (1971). Knowledge and human interest. Boston, MA: Beacon Press.

Habermas, J. (1987). The theory of communicative action. Vol. 2: Lifeworld and system: $A$ critique of functional reason (T. McCarthy, Trans.). Boston, MA: Beacon Press.

Hämäläinen, J. (2012). Social pedagogical eyes in the midst of diverse understandings, conceptualizations, and activities. International Journal of Social Pedagogy, 1(1), 3-16.

Head Start Act, 42 U.S.C. $\int 9831$ (1965).

Henry, G. T., Gordon, C. S., \& Rickman, D. K. (2006). Early education policy alternatives: Comparing quality and outcomes of Head Start and state prekindergarten. Educational Evaluation and Policy Analysis, 28(1), 77-99.

Howe, K. (1997). Understanding equal educational opportunity: Social justice, democracy, and schooling. New York, NY: Teachers College Press.

Hunt, J. M. (1961). Intelligence and experience. New York, NY: Ronald.

Kantor, H., \& Lowe, R. (1995). Class, race, and the emergence of federal education policy: From the New Deal to the Great Society. Educational Researcher, 24(3), 4-11.

Karier, C. J. (1986). The individual, society, and education: A bistory of American educational ideas (2nd ed.). Urbana, IL: University of Illinois Press.

Katz, J. L. (1996). Education programs get a big boost in spending. Congressional Quarterly, $54,2867-70$.

Keddie, N. (1973). The myth of cultural deprivation. London, England: Penguin.

Kliewer, C., \& Biklen, D. (2007). Enacting literacy: Local understanding, significant disability, and a new frame for educational opportunity. Teachers College Record, 109(12), 2579-2600.

Kluth, P., Straut, D. M., \& Biklen, D. P. (2003). Access to academics for all students: Critical approaches to inclusive curriculum, instruction, and policy. Mahwah, NJ: Erlbaum Associates.

Kohn, A. (1998). Only for my kid: How privileged parents undermine school reform. Phi Delta Kappan, 79(8), 569-577.

Lewis, O. (1959). Five families: Mexican case studies in the culture of poverty. New York, NY: Basic Books.

Love, J. M., Kisker, E. E., Ross, C. M., Schochet, P. Z., Brooks-Gunn, J., Paulsell, D., Boller, K., Constantine, J., Vogel, C., Fuligni, A. S., \& Brady-Smith, C. (2002). Making a difference in the lives of infants and toddlers and their families: The impacts of Early Head Start.

Washington, DC: U.S. Department of Health and Human Services, Administration on Children, Youth, and families.

Magnuson, K. A., Meyers, M. K., Ruhm, C. J., \& Waldfogel, J. (2004). Inequality in preschool education and school readiness. American Educational Research Journal, 41(1), 115-157. 
Mead, G. H. (1934). Mind, self, and society from the standpoint of a social behaviorist. Chicago, IL: The University of Chicago Press.

Morrow, H. (2011). Integrating deliberative justice theory into social work policy pedagogy. Journal of Social Work Education, 47(3), 389-402.

Moynihan, D. P. (1969). Maximum feasible misunderstanding: Community action in the $W$ ar of Poverty. New York, NY: The Free Press.

Nash, J. M. (1997, February 3). Fertile minds. Time, 49-56.

Nathan, R. P. (2007). How should we read the evidence about Head Start? Three views. Journal of Policy Analysis and Management, 26(3), 673-689.

National Commission on Excellence in Education (1983). A nation at risk: The imperative for educational reform. Washington, DC: Government Printing Office.

National Institute of Early Education Research (2009). The state of preschool 2009: State preschool yearbook. Rutgers, NJ: Graduate School of Education.

Newcombe, N. (2002). The nativist-empiricist controversy in the context of recent research on spatial and quantitative development. Psychological Science, 13(5), 395-401.

National Institute of Child Health and Human Development Early Childcare Research Network. (2002). Early child care children's development prior to school entry: Results from the NICHD Study of Early Child Care. American Educational Research Journal, 39(1), 133-164.

No Child Left Behind Act of 2001, 107 U.S.C. \1425 (2002).

Perkins-Gough, D. (2007). Giving intervention a Head Start: A conversation with Edward Zigler. Educational Leadership, 65(2), 8-14.

Petrie, P., Boddy, J., Cameron, C., Wigfall, V., \& Simon, A. (2006). Working with children in care: European perspectives. Maidenhead, England: Open University Press.

Petrie, P. (2007). Foster care: A role for social pedagogy? Adoption \& Fostering, 31(1), 73-80.

Piaget, J. (1932/1965). The moral judgment of the child. New York, NY: Free Press.

Piaget, J. (1948/1973). To understand is to invent. New York, NY: Grossman. (Original work published in Prospects, UNESCO Quarterly Review of Education.)

Porter, S. (1998). Social theory and nursing practice. London, England: Macmillan.

Puma, M., Bell, S., Cook, R., Heid, C., Lopez, M., Zill, N., Shapiro, G., Broene, P., Mekos, D., Rohacek, M., Quinn, L., Adams, G., Friedman, J., \& Bernstein, H. (2005). Head Start impact study: First year findings. Washington, DC: U.S. Department of Health and Human Services, Administration for Children and Families.

Rawls, J. (1971). A theory of justice. Cambridge, MA: Belknap Press.

Reardon, S. (2011). The widening academic achievement gap between the rich and the poor: New evidence and possible explanations. In D. J. Duncan \& R. Murnane (Eds.), Whither opportunity? Rising inequality, schools, and children's life chances (pp. 91-116).

Reiter, S. (2000). Society and disability: A model of support in special education and rehabilitation. Focus on Exceptional Children, 32, 1-14.

Ripple, C. H., Gilliam, W. S., Chanana, N., \& Zigler, E. F. (1999). Will fifty cooks spoil the broth? The debate over entrusting Head Start to the states. American Psychologist, 54(5), 327-343.

Rosenthal, R. \& Jacobson, L. (1968). Pygmalion in the classroom: Teacher expectations and pupils' intellectual development. New York, NY: Holt, Rinehart and Winston.

Sailor, W. (2006). Invited commentary: The quest for ordinary lives: A legacy and a challenge to the status quo. Research \& Practice with Severe Disabilities, 31(2), 127-129.

Sawhill, I. (2006). Opportunity in America: The role of education (Future of Children Policy Brief). Washington, DC: Woodrow Wilson School of Public and International 
Affairs at Princeton University \& Brookings Institution.

Scambler, G. (1987). Habermas and the power of medical expertise. In G. Scambler (Ed.), Sociological theory and medical sociology (pp. 165-193). London, England: Tavisock.

Schnog, N. (1997). On inventing the psychological. In J. Pfister \& N. Schnog (Eds.), Inventing the psychological: Toward a cultural history of emotional life in America (pp. 3-16).

New Haven, CT: Yale University Press.

Sergiovanni, T. J. (2000). The lifeworld of leadership. San Francisco, CA: Jossey-Bass.

Shore, R. (1997). Rethinking the brain: New insights into early development. New York, NY: Families and Work Institute.

Sissel, P. A. (2000). Staff, parents, and politics in Head Start: A case study in unequal power, knowledge, and material resources. New York, NY: Falmer Press.

Skrtic, T. M. (1991). Behind special education: A critical analysis of professional culture and school organization. Denver, CO: Love.

Sleeter, C. E. (1996). Radical structuralist perspectives on the creation and use of learning disabilities. In T. M. Skrtic (Ed.), Disability and democracy: Reconstructing (special) education for postmodernity (pp. 153-165). New York, NY: Teachers College Press.

Smith, M. (2012). Social pedagogy from a Scottish perspective. International Journal of Social Pedagogy, 1(1), 46-55.

Storey, K. (1993). A proposal for assessing integration. Education and Training for Mental Retardation, 28, 279-287.

Storey, K. (2004). The case against the Special Olympics. Journal of Disability Policy Studies, $15,35-42$.

Storey, K. (2008). The more things change, the more they are the same: Continuing concerns with the Special Olympics. Research and Practice for Persons with Severe Disabilities, 33(3), 134-142.

U.S. Department of Health and Human Services, Administration for Children and Families. (2005). Head Start impact study: First year findings. Washington, DC: Author.

U.S. Department of Health and Human Services, Administration for Children and Families. (2010). Head Start impact study: Final report. Washington, DC: Author.

U.S. General Accounting Office. (1997). Head Start: Research provides little information on impact of current program. Washington, DC: Author.

Vinovskis, M. A. (1993). Early childhood education: Then and now. Daedalus, 122, 151-176.

Vinovskis, M. A. (1995). School readiness and early childhood education. In D. Ravitch \& M. A. Vinovskis (Eds.), Learning from the past: What history teaches us about school reform. Baltimore, MD: John Hopkins University Press.

Vinovskis, M. A. (1999). Do federal compensatory education programs really work? A brief historical analysis of Title I and Head Start. American Journal of Education, 107, 187209.

Vinovskis, M. A. (2008). The birth of Head Start: Preschool education policies in the Kennedy and Johnson administrations. Chicago, IL: University of Chicago Press.

Wagner, T., \& Kegan, R. (2006). Change leadership: A practical guide to transforming our schools. San Francisco, CA: Jossey-Bass.

Westinghouse Learning Corporation. (1969). The impact of Head Start: An evaluation of the effects of Head Start on children's cognition and affective development. Washington, DC: Clearinghouse for Federal Scientific and Technical Information Document No. ED036321 (Ohio University Report to the Office of Economic Opportunity, Contract No. B89-4536). 
Zarefsky, D. (1986). President Johnson's War on Poverty: Rhetoric and history. Tuscaloosa, AL: University of Alabama Press.

Zigler, E., \& Anderson, K. (1979). An idea whose time has come; The intellectual and political climate. In E. Zigler \& J. Valentine (Eds.), Project Head Start: A legacy of the War on Poverty (pp. 3-19). New York, NY: The Free Press.

Zigler, E., \& Finn-Stevenson, M. (2007). From research to policy and practice: The school of the $21^{\text {st }}$ century. American Journal of Orthopsychiatry, 77(2), 175-181. 


\section{About the Authors}

\section{Shelly Counsell}

University of Memphis

Email: slcnsell@memphis.edu

Shelly Counsell is Assistant Professor of Early Childhood Education at the University of Memphis. Her research interests include early physical science, high-stakes testing, disability studies, diversity, social justice, and critical theory.

\section{Robert M. Boody}

University of Northern Iowa

Email: Robert.Boody@uni.edu

Robert M. Boody is Associate Professor of Educational Psychology and Foundations at the University of Northern Iowa. His research interests include teacher knowledge and change, philosophy of inquiry, and accountability systems in the preparation of educators.

\section{Daniel Schugurensky}

\section{About the Guest Co-Editors}

Arizona State University

Email: dschugur@asu.edu

Daniel Schugurensky is Full professor at Arizona State University, where he has joint appointment in the School of Public Affairs and the School of Social Transformation. He is the Head of the Area of Justice and Social Inquiry, and the coordinator of the Masters program in social and cultural pedagogy. He has written extensively on youth and adult education, community development and participatory democracy. Among his recent authored and coedited books are Ruptures, continuities and re-learning: The political participation of Latin Americans in Canada (Transformative Learning Centre, University of Toronto, 2006), Four in Ten: Spanish-Speaking Youth and Early School Leaving in Toronto (LARED, 2009), Learning citizenship by practicing democracy: international initiatives and perspectives (Cambridge Scholarly Press, 2010), Paulo Freire (Continuum, 2011), and Volunteer work, informal learning and social action (Sense 2013).

\section{Michael Silver}

Arizona State University

Email: Michael.Silver@asu.edu

Michael Silver is a Research Fellow at the National Center on Education and the Economy and the Center for the Future of Arizona. As a Doctoral Student in Educational Policy and Evaluation, his research focuses on policies affecting educational equity and issues of social justice - particularly those related to historically vulnerable, minority populations. 


\section{SPECIAL ISSUE Social Pedagogy in the $21^{\text {st }}$ Century education policy analysis archives}

\section{@)}

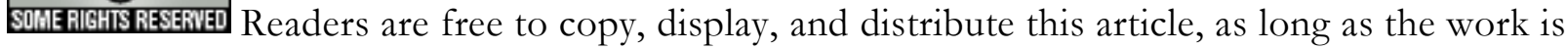
attributed to the author(s) and Education Policy Analysis Archives, it is distributed for noncommercial purposes only, and no alteration or transformation is made in the work. More details of this Creative Commons license are available at http://creativecommons.org/licenses/by-nc-sa/3.0/. All other uses must be approved by the author(s) or EPAA. EPAA is published by the Mary Lou Fulton Institute and Graduate School of Education at Arizona State University Articles are indexed in CIRC (Clasificación Integrada de Revistas Científicas, Spain), DIALNET (Spain), Directory of Open Access Journals, EBSCO Education Research Complete, ERIC, Education Full Text (H.W. Wilson), QUALIS A2 (Brazil), SCImago Journal Rank; SCOPUS, SOCOLAR (China).

Please contribute commentaries at http://epaa.info/wordpress/ and send errata notes to Gustavo E. Fischman fischman@asu.edu

Join EPAA's Facebook community at https://www.facebook.com/EPAAAAPE and Twitter feed @epaa_aape. 


\section{education policy analysis archives editorial board}

\section{Editor Gustavo E. Fischman (Arizona State University)}

Associate Editors: David R. Garcia (Arizona State University), Stephen Lawton (Arizona State University)

Rick Mintrop, (University of California, Berkeley) Jeanne M. Powers (Arizona State University)

Jessica Allen University of Colorado, Boulder

Gary Anderson New York University

Michael W. Apple University of Wisconsin, Madison

Angela Arzubiaga Arizona State University

David C. Berliner Arizona State University

Robert Bickel Marshall University

Henry Braun Boston College

Eric Camburn University of Wisconsin, Madison

Wendy C. Chi* University of Colorado, Boulder

Casey Cobb University of Connecticut

Arnold Danzig Arizona State University

Antonia Darder University of Illinois, UrbanaChampaign

Linda Darling-Hammond Stanford University

Chad d'Entremont Strategies for Children

John Diamond Harvard University

Tara Donahue Learning Point Associates

Sherman Dorn University of South Florida

Christopher Joseph Frey Bowling Green State University

Melissa Lynn Freeman* Adams State College

Amy Garrett Dikkers University of Minnesota

Gene V Glass Arizona State University

Ronald Glass University of California, Santa Cruz

Harvey Goldstein Bristol University

Jacob P. K. Gross Indiana University

Eric M. Haas WestEd

Kimberly Joy Howard* University of Southern California

Aimee Howley Ohio University

Craig Howley Ohio University

Steve Klees University of Maryland

Jaekyung Lee SUNY Buffalo
Christopher Lubienski University of Illinois, UrbanaChampaign

Sarah Lubienski University of Illinois, UrbanaChampaign

Samuel R. Lucas University of California, Berkeley

Maria Martinez-Coslo University of Texas, Arlington

William Mathis University of Colorado, Boulder

Tristan McCowan Institute of Education, London

Heinrich Mintrop University of California, Berkeley

Michele S. Moses University of Colorado, Boulder

Julianne Moss University of Melbourne

Sharon Nichols University of Texas, San Antonio

Noga O'Connor University of Iowa

João Paraskveva University of Massachusetts, Dartmouth

Laurence Parker University of Illinois, UrbanaChampaign

Susan L. Robertson Bristol University

John Rogers University of California, Los Angeles

A. G. Rud Purdue University

Felicia C. Sanders The Pennsylvania State University

Janelle Scott University of California, Berkeley

Kimberly Scott Arizona State University

Dorothy Shipps Baruch College/CUNY

Maria Teresa Tatto Michigan State University

Larisa Warhol University of Connecticut

Cally Waite Social Science Research Council

John Weathers University of Colorado, Colorado Springs

Kevin Welner University of Colorado, Boulder

Ed Wiley University of Colorado, Boulder

Terrence G. Wiley Arizona State University

John Willinsky Stanford University

Kyo Yamashiro University of California, Los Angeles

* Members of the New Scholars Board 


\section{archivos analíticos de políticas educativas consejo editorial}

Editor: Gustavo E. Fischman (Arizona State University)

Editores. Asociados Alejandro Canales (UNAM) y Jesús Romero Morante (Universidad de Cantabria)

Armando Alcántara Santuario Instituto de Investigaciones sobre la Universidad y la Educación, UNAM México

Claudio Almonacid Universidad Metropolitana de Ciencias de la Educación, Chile

Pilar Arnaiz Sánchez Universidad de Murcia, España

Xavier Besalú Costa Universitat de Girona, España Jose Joaquin Brunner Universidad Diego Portales, Chile

Damián Canales Sánchez Instituto Nacional para la Evaluación de la Educación, México

María Caridad García Universidad Católica del Norte, Chile

Raimundo Cuesta Fernández IES Fray Luis de León, España

Marco Antonio Delgado Fuentes Universidad Iberoamericana, México

Inés Dussel FLACSO, Argentina

Rafael Feito Alonso Universidad Complutense de Madrid, España

Pedro Flores Crespo Universidad Iberoamericana, México

Verónica García Martínez Universidad Juárez Autónoma de Tabasco, México

Francisco F. García Pérez Universidad de Sevilla, España

Edna Luna Serrano Universidad Autónoma de Baja California, México

Alma Maldonado Departamento de Investigaciones Educativas, Centro de Investigación y de Estudios Avanzados, México

Alejandro Márquez Jiménez Instituto de Investigaciones sobre la Universidad y la Educación, UNAM México

José Felipe Martínez Fernández University of California Los Angeles, USA
Fanni Muñoz Pontificia Universidad Católica de Perú

Imanol Ordorika Instituto de Investigaciones Economicas - UNAM, México

Maria Cristina Parra Sandoval Universidad de Zulia, Venezuela

Miguel A. Pereyra Universidad de Granada, España

Monica Pini Universidad Nacional de San Martín, Argentina

Paula Razquin UNESCO, Francia

Ignacio Rivas Flores Universidad de Málaga, España

Daniel Schugurensky Arizona State University

Orlando Pulido Chaves Universidad Pedagógica Nacional, Colombia

José Gregorio Rodríguez Universidad Nacional de Colombia

Miriam Rodríguez Vargas Universidad Autónoma de Tamaulipas, México

Mario Rueda Beltrán Instituto de Investigaciones sobre la Universidad y la Educación, UNAM México

José Luis San Fabián Maroto Universidad de Oviedo, España

Yengny Marisol Silva Laya Universidad Iberoamericana, México

Aida Terrón Bañuelos Universidad de Oviedo, España

Jurjo Torres Santomé Universidad de la Coruña, España

Antoni Verger Planells University of Amsterdam, Holanda

Mario Yapu Universidad Para la Investigación Estratégica, Bolivia 


\section{arquivos analíticos de políticas educativas conselho editorial}

Editor: Gustavo E. Fischman (Arizona State University) Editores Associados: Rosa Maria Bueno Fisher e Luis A. Gandin

(Universidade Federal do Rio Grande do Sul)

Dalila Andrade de Oliveira Universidade Federal de Minas Gerais, Brasil

Paulo Carrano Universidade Federal Fluminense, Brasil

Alicia Maria Catalano de Bonamino Pontificia Universidade Católica-Rio, Brasil

Fabiana de Amorim Marcello Universidade Luterana do Brasil, Canoas, Brasil

Alexandre Fernandez Vaz Universidade Federal de Santa Catarina, Brasil

Gaudêncio Frigotto Universidade do Estado do Rio de Janeiro, Brasil

Alfredo M Gomes Universidade Federal de Pernambuco, Brasil

Petronilha Beatriz Gonçalves e Silva Universidade Federal de São Carlos, Brasil

Nadja Herman Pontificia Universidade Católica -Rio Grande do Sul, Brasil

José Machado Pais Instituto de Ciências Sociais da Universidade de Lisboa, Portugal

Wenceslao Machado de Oliveira Jr. Universidade Estadual de Campinas, Brasil
Jefferson Mainardes Universidade Estadual de Ponta Grossa, Brasil

Luciano Mendes de Faria Filho Universidade Federal de Minas Gerais, Brasil

Lia Raquel Moreira Oliveira Universidade do Minho, Portugal

Belmira Oliveira Bueno Universidade de São Paulo, Brasil

António Teodoro Universidade Lusófona, Portugal

Pia L. Wong California State University Sacramento, U.S.A

Sandra Regina Sales Universidade Federal Rural do Rio de Janeiro, Brasil

Elba Siqueira Sá Barreto Fundação Carlos Chagas, Brasil

Manuela Terrasêca Universidade do Porto, Portugal

Robert Verhine Universidade Federal da Bahia, Brasil

Antônio A. S. Zuin Universidade Federal de São Carlos, Brasil 